\title{
PENGEMBANGAN BAHAN AJAR AKUNTANSI BERBASIS KOMPUTER UNTUK SMK PROGRAM KEAHLIAN BISNIS \& MANAJEMEN SE-KOTA MALANG
}

\author{
Diana Tien Irafahmi \\ Endang Sri Andayani \\ Universitas Negeri Malang \\ dianairafahmi@gmail.com
}

\begin{abstract}
This developmental research is aimed to develop computer-based accounting learning material. This research was conducted based on the fact that the implementation of competency-based curriculum for vocational high school of economics is dealing with some constraints, for instance misconception of accounting teacher to understand the substance of competency-based curriculum. The learning material was designed based on the findings obtained from field research and curriculum content analysis conducted in advance. The research has developed computer-based accounting learning material that has been validated using expert judgment validation technique. The learning material covers: (1) case that can be reconstructed by teachers; and (2) worksheet consisting of document of transaction, journal, general ledger, trial balance, and financial statement. To be widely implemented, the learning material needs to be tested through classroom experiment to ensure its effectiveness.
\end{abstract}

Keywords: accounting, teaching material, computer

\begin{abstract}
Abstrak: Penelitian pengembangan ini ditujukan untuk mengembangkan bahan ajar akuntansi berbasis komputer. Penelitian ini dilakukan berdasarkan fakta bahwa implementasi kurikulum berbasis kompetensi pada SMK program bisnis dan manajemen menemui beberapa kendala diantaranya mencakup miskonsepsi guru dalam memahami hakekat kurikulum berbasis kompetensi. Bahan ajar didesain berdasarkan temuan dari penelitian di lapangan maupun dari analisis isi kurikulum yang telah dilakukan sebelumnya. Luaran dari penelitian ini adalah bahan ajar akuntansi berbasis komputer yang telah divalidasi menggunakan teknik validasi berupa professional judgment dari ahli. Secara umum komponen bahan ajar mencakup: (1) kasus, yang bisa diupgrade oleh guru, serta (2) worksheet yang terdiri dari bukti transaksi, jurnal, buku besar, neraca saldo dan laporan keuangan. Agar bisa diimplementasikan secara luas, bahan ajar ini perlu diujicobakan terlebih dahulu di kelas dengan desain eksperimen untuk mendapatkan keyakinan tentang tingkat keefektifan dari penggunaan bahan ajar.
\end{abstract}

Kata kunci: akuntansi, bahan ajar, komputer

SMK Bisnis Manajemen pada dasarnya merupakan program pendidikan pada jenjang pendidikan menengah yang mengutamakan pengembangan kemampuan peserta didik untuk dapat bekerja dalam bidang tertentu, kemampuan beradaptasi di lingkungan kerja, 
melihat peluang kerja, dan mengembangkan diri di kemudian hari (Kurikulum SMK 2004). Namun demikian, hasil observasi empirik yang dilakukan di lapangan mengindikasikan bahwa sebagian besar lulusan Sekolah Menengah Kejuruan (SMK) kurang mampu menyesuaikan diri dengan perubahan maupun perkembangan ilmu pengetahuan dan teknologi, sulit untuk bisa dilatih kembali, dan kurang bisa mengembangkan diri. Temuan tersebut tampaknya mengindikasikan bahwa pembelajaran di SMK belum banyak menyentuh atau mengembangkan kemampuan adaptasi peserta didik. Hal ini seperti yang dijelaskan dalam Kurikulum SMK 2004 bahwa sebagian lulusan SMK tidak bisa diserap di lapangan kerja, karena kompetensi yang mereka miliki belum sesuai dengan tuntutan dunia kerja (Kurikulum SMK 2004).

Ketidaksesuaian kompetensi yang dimiliki lulusan SMK dengan dunia kerja terutama banyak disebabkan oleh pembelajaran yang kurang sesuai dengan aktivitas praktis di dunia kerja. Hal ini dapat di lihat pada jurusan Akuntansi di SMK Bisnis Manajemen, di mana pemberian bekal pengetahuan dan ketrampilan akuntansi masih banyak menggunakan textbook Akuntansi dan kurang menggunakan transaksi-transaksi bisnis riil di sekitar siswa. Kelemahan lainnya adalah pemberian bekal ketrampilan di bidang teknologi informasi dan komunikasi (TIK) bersifat terpisah (dan bukan terpadu) dengan ketrampilan utamanya (bidang akuntansi). Hal ini dapat dilihat dari sajian Mata Diklat Akuntansi, di mana Mata Diklat Keterampilan Komputer dan Pengelolaan Informasi merupakan Mata Diklat Adaptif yang terpisah dengan Mata Diklat Produktif Akuntansi. Hal ini mengakibatkan kegiatan pembelajaran hanya mampu melatih ketrampilan pembukuan secara manual, namun kurang memberikan ketrampilan yang sensitif terhadap perkembangan teknologi (khususnya tehnologi komputer), di mana di era global pemanfaatan teknologi komputer akan menjadi bagian dari setiap aktivitas bisnis.

Kajian kurikulum SMK yang diterbitkan Pusat Kurikulum juga menyatakan bahwa bahan ajar yang digunakan di SMK sampai saat ini belum memenuhi standar kompetensi lulusan baik secara kuantitatif, kualitatif dan relevansi. Salah satu alternatif pemecahan masalah yang ditawarkan adalah dengan melakukan optimalisasi dan revitalisasi bahan ajar dan proses belajar yang dapat mengadaptasikan peserta didik dengan lingkungannya dan dunia kerja (Pusat Kurikulum, 2007). Dari penelitian terdahulu.yang dilakukan peneliti (Andayani, dkk. 2009; Irafahmi, 2008) diketahui bahwa preferensi gaya belajar dan pilihan kemasan bahan ajar peserta didik 
(mahasiswa) program akuntansi mulai bergeser dari yang semula textbook oriented menuju ke bahan ajar digital. Temuan ini mengindikasikan perlunya variasi bentuk bahan ajar yang mampu mengintegrasikan kemampuan di bidang akuntansi dengan praktik dunia bisnis yang sarat dengan penggunaan teknologi komputer.

Bahan ajar (instructional materials) merupakan seperangkat pengetahuan, ketrampilan dan sikap yang harus dipelajari siswa dalam rangka mencapai tujuan pembelajaran yang telah ditentukan. Materi pembelajaran ini disusun secara sistematis baik tertulis maupun tidak sehingga tercipta lingkungan/suasana yang memungkinkan siswa untuk belajar. Ada beberapa hal yang harus diperhatikan dalam menentukan bahan ajar (Ibrahim \& Syaodih, 2003, Tim Pustaka Yustisia, 2007), yaitu: (1) bahan ajar hendaknya menunjang tercapainya tujuan pembelajaran (relevansi antara tujuan dengan materi); (2) bahan ajar hendaknya sesuai dengan tingkat pendidikan/perkembangan siswa pada umumnya; (3) bahan ajar harus menunjang ketercapaian tujuan pembelajaran; (4) bahan ajar hendaknya terorganisir secara sistematik dan berkesinambungan; (5) bahan ajar hendaknya cukup memadai dalam membantu siswa menguasai kompetensi dasar yang diajarkan (prinsip kecukupan).

Pengembangan bahan ajar dimaksudkan agar guru tidak terpaku/sepenuhnya mengandalkan pada bahan ajar konvensional seperti buku teks dari penulis lain, tetapi diharapkan guru mampu menciptakan bahan ajar sendiri yang sesuai dengan kondisi siswa, kurikulum dan IPTEK. Bahan ajar yang bisa diciptakan guru dapat diramu dari berbagai sumber bahan ajar. Sumber bahan ajar merupakan tempat/pihak dimana bahan ajar dapat diperoleh, yang antara lain terdiri dari material cetak, multimedia, lingkungan dan orang.

Dari berbagai sumber bahan ajar yang disebutkan di atas, guru selanjutnya diharapkan untuk menyusun dan mengembangkan bahan ajar sendiri yang dapat dikemas dalam berbagai bentuk, antara lain: (1) Bahan ajar cetak, misalnya handout, buku ajar/modul, LKS (Lembar Kerja Siswa, poster; (2) Audio visual, misalnya video/film, VCD, radio, kaset, CD Audio, foto, gambar, model/maket; atau (3) bahan ajar berbasis komputer misalnya CD interaktif, multimedia berbasis internet.

Tujuan dari penelitian ini adalah mengembangkan bahan ajar akuntansi berbasis komputer yang dekat dengan praktik dunia bisnis dan adaptif terhadap penggunaaan 
teknologi komputer, sehingga diharapkan mampu membentuk perilaku yang friendly terhadap dunia praktis dan terhadap teknologi komputer. Hal ini sejalan dengan pencapaian kompetensi pada mata diklat akuntansi yang pada dasarnya lebih menekankan ranah kognitif dan psikomotor. Pencapaian ranah kognitif lebih diarahkan pada peningkatan dan atau pemantapan kompentensi memahami aturan dan dalil dalam akuntansi. Adapun pencapaian ranah psikomotor diarahkan pada kemampuan mahasiswa memanfaatkan teknologi komputer untuk memecahkan masalah-masalah akuntansi. Melalui mata diklat ini diharapkan siswa memiliki pengalaman praktik menyelesaikan kasus-kasus akuntansi. Memberi pengalaman praktis berarti memberi masukan wawasan dan ilmu pengetahuan, serta psikomotor dengan tingkah laku dan akhlak mulia serta pembinaan ketrampilan kepemimpinan yang visioner dan bijaksana.

Menurut Moore (2005) indikator kecakapan dari aspek psikomotor meliputi: observing (memperhatikan); imitation (peniruan), practicing (latihan/pembiasaan), dan adapting (penyesuaian). Sesuai pendapat ini maka pencapaian kompetensi psikomotor di bidang teknologi komputer melalui aktivitas latihan/pembiasaan memegang peranan penting guna "mendarahdagingkan" kemampuan menggunakan teknologi tersebut. Tanpa latihan dan pembiasaan sangat tidak mungkin orang menguasai ketrampilan yang diinginkannya. Oleh karena itu di era teknologi informasi dan komunikasi, membiasakan setiap aktivitas belajar dengan selalu bersentuhan dengan teknologi tersebut (khususnya komputer) menjadi sangat penting.

Berbagai penelitian telah banyak dilakukan oleh penelitian sebelumnya tentang efektifitas penggunaan media yang diukur dari peningkatan hasil belajar. Siswa yang dalam pembelajaran di kelasnya menggunakan multimedia secara signifikan lebih berhasil dibanding kelas dengan pembelajaran tradisional (Ghee \& Heng, 2008). Penggunaan multimedia yang mengkombinasikan penggunaan teks, seni grafis, suara, animasi, dan elemen video juga terbukti mampu mensinkronkan belajar siswa (LeeTiernan \& Grudin, 2001 dalam Ghee \& Heng, 2008).

Penggunaan multi media dalam sistem pendidikan saat ini diklaim secara luas dapat meningkatkan efektifitas dan efisiensi pembelajaran bahasa (e.g., Christmann, Badgett, \& Lucking, 1977; Kulik \& Kulik, 1991, dalam Liu, 2000), begitu pula membantu siswa untuk mendapatkan pengetahuan secara lebih efektif (Liu, 2000). 


\section{METODE}

Penelitian ini merupakan penelitian pengembangan (Research \& Development). Jenis penelitian pengembangan (Research \& Development) banyak digunakan untuk memecahkan masalah praktis dalam bidang pendidikan. Hal ini sebagaimana dinyatakan oleh Borg \& Gall (1983) bahwa penelitian pengembangan adalah suatu proses yang digunakan untuk mengembangkan dan memvalidasi produk pendidikan.

Seluruh tahapan penelitian ini direncanakan melalui dua tahap/dua tahun. Tahun pertama digunakan untuk kegiatan analisis kebutuhan dan perancangan prototipe bahan ajar, sedangkan pada tahun kedua difokuskan pada pelaksanaan eksperimen dan revisi bahan ajar akuntansi untuk menghasilkan bentuk final bahan ajar berbasis komputer. Penelitian pada tahap pertama ini meliputi empat tahap kegiatan sesuai model pengembangan Borg \& Gall, yaitu: (1) tahap awal; (2) tahap desain; (3) tahap validasi; dan (4) tahap revisi. Adapun alur kegiatan dapat digambarkan sebagai berikut.

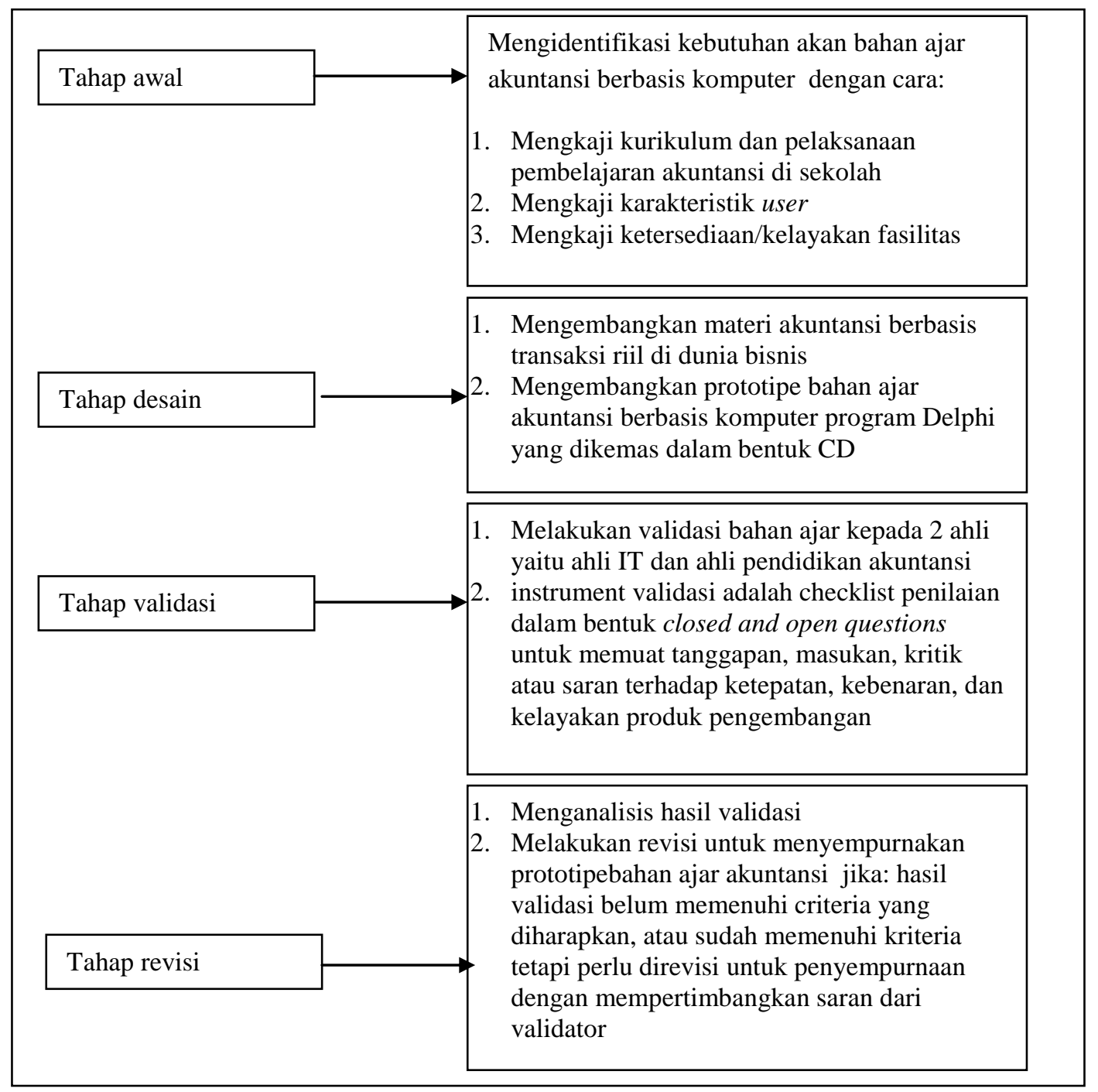

Gambar 1. Alur kegiatan Penelitian 
Penelitian pada tahap awal dimaksudkan untuk memperoleh pemahaman atas kurikulum SMK serta data empiris atas praktek pembelajaran akuntansi di SMK. Penelitian dilakukan pada SMK di Malang. SMK yang terpilih diambil berdasarkan teknik purposive sampling. Kriteria yang digunakan untuk memilih sampel SMK adalah sebagai berikut: (1) Sekolah yang dipilih adalah SMK yang terdapat program keahlian akuntansi; (2) Sekolah yang dipilih adalah representasi dari sekolah negeri dan swasta. Sekolah negeri diwakili oleh SMKN 1 Malang, sedangkan sekolah swasta diwakili oleh SMK PGRI 6 Malang dan SMK Muhamadiyah 5.

Validasi dilakukan untuk menentukan kebenaran, ketepatan dan kelayakan produk pengembangan. Validasi atas bahan ajar akuntansi yang dikembangkan dilakukan oleh 2 orang pakar, yaitu pakar di bidang IT (informasi dan teknologi) serta pakar di bidang pendidikan akuntansi. Instrumen validasi adalah checklist penilaian yang dirancang dalam bentuk closed dan open questions untuk memuat tanggapan, masukan, kritikan dan saran dari validator. Pilihan jawaban untuk closed question adalah sangat sesuai/sesuai/kurang sesuai/tidak sesuai. Sedangkan untuk open questions digunakan untuk mendapatkan masukan tentang kekuatan, kelemahan dan tanggapan secara umum dari validator atas produk pengembangan.

Teknik pengumpulan data untuk mendapatkan data tentang praktek pembelajaran akuntansi dikumpulkan dari para guru akuntansi SMK dengan menggunakan teknik wawancara mendalam. Data yang diperoleh dari hasil wawancara tersebut kemudian dianalisis dengan menggunakan pendekatan deskriptif kualitatif, yang terdiri dari proses reduksi data, infering dan penarikan kesimpulan. Adapun pengumpulan data yang berasal dari telaah literatur dilakukan dengan teknik analisis isi (content analysis).

Pengumpulan data validasi dilakukan dengan menggunakan instrumen angket dan dianalisis secara deskriptif. Dengan memperhatikan kriteria tersebut dipadukan dengan masukan dalam bentuk opini terbuka validator atas kekuatan, kelemahan, dan tanggapan umum atas produk pengembangan, maka akan diketahui valid/andal tidaknya produk pengembangan. Apabila dari hasil validasi ahli diketahui bahwa produk pengembangan perlu direvisi, maka dilakukan revisi/penyempurnaan sampai diperoleh prototipe produk pengembangan yang berkualitas. 


\section{HASIL DAN PEMBAHASAN}

\section{Praktek Pembelajaran di SMK}

Dalam setiap aktivitas pembelajaran di sekolah, guru menggunakan kurikulum sebagai acuan untuk memberikan pengalaman belajar bagi anak didiknya. Di SMK Bisnis Manajemen, kurikulum yang ditetapkan oleh Dinas Pendidikan adalah Kurikulum KBK 2004 yang menjadi landasan bagi pengembangan Kurikulum Tingkat Satuan Pendidikan maupun Spektrum Akuntansi. Sesuai dengan penjelasan dalam kurikulum yang dimaksud, kurikulum ini dikembangkan sebagai reaksi dari lemahnya kemampuan siswa untuk beradaptasi dengan lingkungannya serta perkembangan ilmu pengetahuan dan teknologi.

Secara khusus tujuan Program Keahlian Akuntansi adalah membekali peserta didik dengan keterampilan, pengetahuan dan sikap agar kompeten: (1) meningkatkan keimanan dan ketaqwaan peserta diklat; (2) mendidik peserta diklat agar menjadi warga negara yang bertanggung jawab; (3) mendidik peserta diklat agar dapat menerapkan hidup sehat, memiliki wawasan pengetahuan dan seni; (4) mendidik peserta diklat dengan keahlian dan keterampilan dalam bidang keahlian Bisnis dan Manajemen khususnya Program Keahlian Akuntansi agar dapat bekerja baik secara mandiri atau mengisi lowongan pekerjaan yang ada di dunia usaha dan dunia industri sebagai tenaga kerja tingkat menengah; (5) mendidik peserta diklat agar mampu memilih karir, berkompetisi, dan mengembangkan sikap profesional dalam bidang keahlian Bisnis dan Manajemen khususnya Program Keahlian Akuntansi; (6) membekali peserta diklat dengan ilmu pengetahuan dan keterampilan sebagai bekal bagi yang berminat untuk melanjuntukan pendidikan.

Berdasar pada tujuan tersebut maka pengembangan program pembelajaran lebih diarahkan pada mempersiapkan lulusan dengan kualifikasi level pemegang buku. Hal ini juga disesuaikan dengan jenis pekerjaan atau profesi yang relevan dengan kompetensi yang tertuang di dalam tabel SKKNI keahlian Akuntansi jenjang SMK Akuntansi yang secara umum adalah sebagai operator komputer, operator mesin ketik, operator telepon, dan pemegang buku. Oleh karena itu kompetensi sebagai pemegang buku lebih diarahkan pada kompetensi mengelola bukti transaksi dan pembukuan untuk beberapa aktivitas utama di perusahaan, bukan sebagai analis seperti kompetensi yang ingin dicapai pada level perguruan tinggi. 
Sementara hasil penelitian lapangan untuk pengumpulan informasi empiris tentang pelaksanaan pembelajaran akuntansi di SMK memperoleh temuan-temuan yang secara ringkas dapat dipaparkan sebagai berikut: (1) Belum semua guru memahami esensi tujuan kurikuler dari kurikulum berbasis kompetensi SMK Bisnis \& Manajemen. Selain itu, perubahan isi kurikulum 1999 ke kurikulum 2004 belum sepenuhnya diterima oleh guru; (2) Belum difahaminya esensi tujuan kurikuler Kurikulum 2004 serta perbedaan materi antara kurikulum 2004 dengan materi uji kompetensi mengakibatkan kebingungan guru dalam merumuskan tujuan serta kompetensi yang harus dicapai oleh anak didiknya. Namun sebagian besar guru cenderung mengarahkan tujuan pembelajarannya sesuai dengan tuntutan uji kompetensi akuntansi; (3) Karena miskonsepsi tentang kompetensi yang harus dicapai siswanya tersebut, mengakibatkan guru hanya memanfaatkan bahan ajar buku teks berbasis transaksi rekaan dan bahan ajar yang dikembangkan oleh lembaga pendidikan di luar sekolah.; (4) Miskonsepsi tersebut juga mengakibatkan metode pembelajaran yang digunakan masih konvensional, yakni ceramah, tanya jawab, dan pemberian tugas. Sementara kurikulum 2004 lebih memberikan peluang kepada guru menggunakan pendekatan konstekstual dalam pembelajarannya. Hal ini kemungkinan disebabkan oleh sulitnya memperoleh bukti transaksi riil di dunia bisnis; (5) Mispersepsi tentang pemanfaatan media komputer serta rendahnya kompetensi guru di bidang ICT, mengakibatkan guru kurang kreatif dalam merancang media pembelajaran. Walaupun siswa telah mempunyai kemampuan yang memadai di bidang ICT dan sekolah telah menyediaan media komputer yang memadai untuk kegiatan pembelajaran, namun guru belum memanfaatkan peluang ini

Berdasarkan beberapa temuan di atas, maka alternatif pengembangan bahan ajar akuntansi berbasis komputer yang sesuai dengan situasi dan kondisi guru, siswa, dan sekolah adalah sebagai berikut: (1) Berbasis bukti transaksi riil. Artinya, kasus-kasus yang dikembangkan dalam bahan ajar ini lebih didekatkan dengan kasus riil di dunia usaha. Bukti-bukti transaksi unik tiap jenis perusahaan akan memberikan pemahaman yang lebih kepada siswa tentang isi dan bentuk bukti transaksi yang ada di dunia bisnis; (2) Sistem sederhana dan mudah difahami, artinya bahwa sistem yang dikembangkan harus mudah dioperasikan. Penekanan bahan ajar ini lebih ditekankan pada memberikan pengalaman riil mengelola bukti tansaksi dan pencatatannya serta menguatkan guru dan siswa untuk lebih "melek" ICT; (3) Guru bisa mengupgrade/menambahkan kasus dan bukti transaksi, artinya bahwa program yang dikembangkan harus memberikan peluang 
kepada guru untuk memperbaiki kasus dan menambah bukti transaksi sesuai dengan keinginan guru; (4) Dikemas dalam CD sehingga lebih murah. Bahan ajar dengan basis bukti transaksi riil akan membutuhkan jumlah halaman yang relatif banyak jika dikemas dalam hardcopy. Oleh karena itu, pengembangan bahan ajar yang dikemas dalam CD selain memudahkan siswa dalam melatih kemampuan akuntansinya juga mengurangi biaya fotocopy yang relatif lebih mahal.

Secara ringkas hasil analisis yang dimaksud digambarkan sebagai berikut.

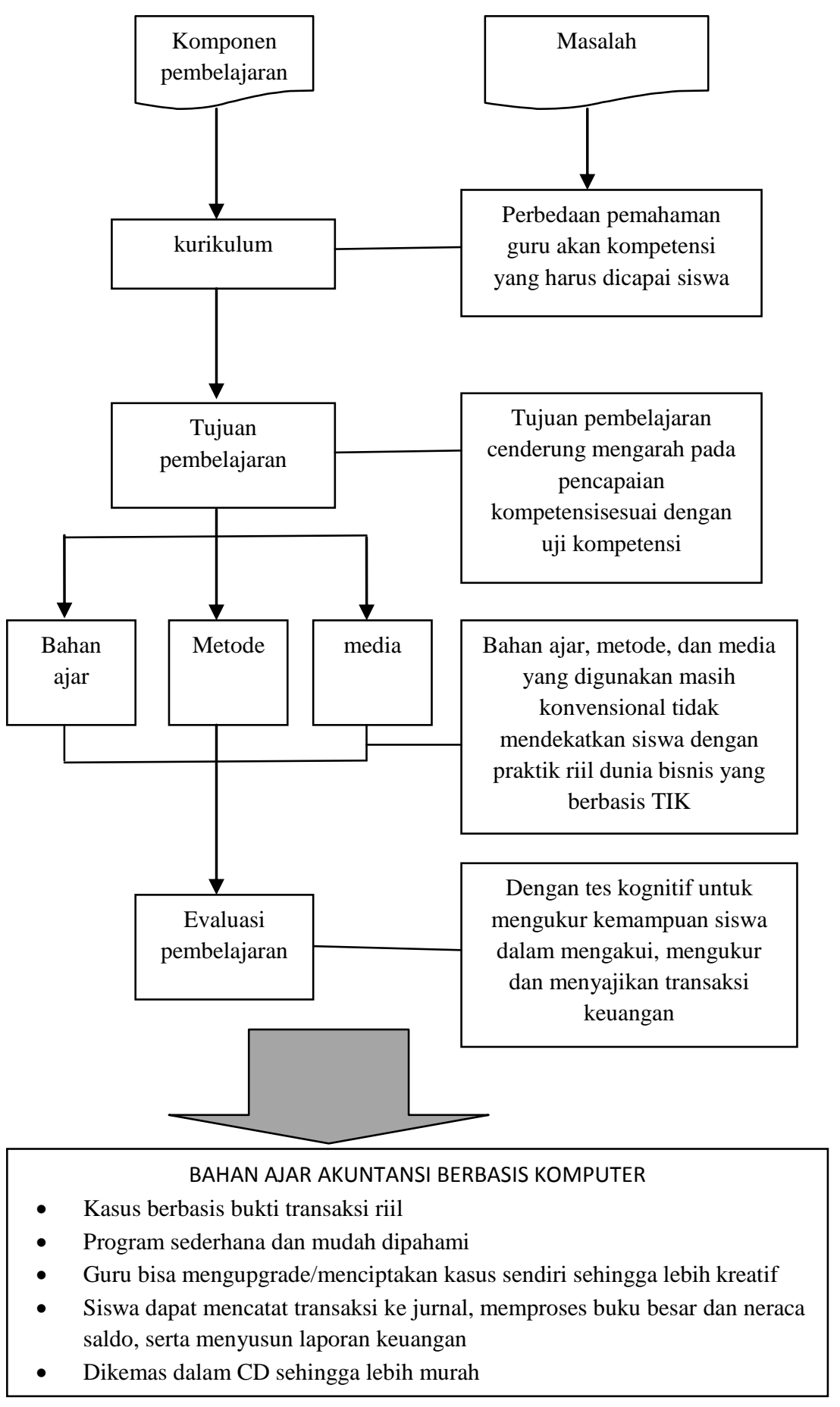

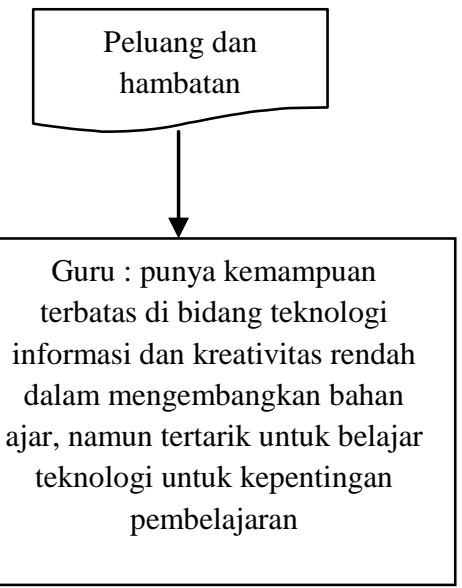

Siswa : punya kemampuan memadai di bidang TIK, motivasi belajar tinggi dengan menggunakan teknologi tapi tidak difasilitasi dalam pembelajaran

Siswa : punya kemampuan memadai di bidang TIK, motivasi belajar tinggi dengan menggunakan teknologi tapi tidak difasilitasi dalam pembelajaran

Sarana Prasarana: tersedia lab komputer yang memadai, namun hanya dimanfaatkan untuk pembelajaran KKPI dan MYOB.

Telah tersedia LCD yang bisa digunakan di kelas tapi belum dimanfaatkan guru 


\section{Hasil pengembangan bahan ajar}

Prototipe bahan ajar akuntansi berbasis komputer dalam penelitian ini didasarkan atas hasil penelitian baik yang berasal dari analisis kurikulum maupun dari analisis praktek pembelajaran di SMK. Topik kompetensi yang menjadi fokus penelitian ini adalah topik-topik kompetensi yang dialokasikan untuk siswa kelas X SMK yang terdiri dari mengelola dokumen transaksi, mengelola entri jurnal, memproses buku besar dan neraca saldo, serta menyusun laporan keuangan. Secara umum, program terbagi dalam dua bagian besar yaitu kasus dan kertas kerja. Kasus dalam program dirancang dengan berbasis bukti transaksi riil khususnya untuk transaksi eksternal. Kertas kerja terdiri dari bukti transaksi, jurnal, buku besar, neraca saldo, dan laporan keuangan. Program telah dirancang untuk dapat ditambahkan variasi kasus dan kertas kerja sehingga dapat mendorong guru (maupun siswa) untuk lebih kreatif dalam membuat kasus-kasus baru. Pada tampilan awal, terdapat 6 menu utama yang terdiri dari menu master, bukti transaksi, proses, laporan, help dan exit.

Untuk memastikan kelayakan prototipe bahan ajar, dilakukan validasi dengan teknik expert judgment yaitu dilakukan dengan cara meminta pendapat ahli tentang prototipe bahan ajar akuntansi berbasis komputer yang dihasilkan sekaligus meminta masukan untuk kepentingan penyempurnaan prototipe produk. Tim ahli sebagai validator dalam penelitian ini terdiri dari 2 orang (satu orang programmer dan satu orang dosen akuntansi senior). Validasi difokuskan pada 2 aspek penilaian, yaitu (1) aspek teknis, dan (2) aspek edukatif. Validasi untuk menilai ketepatan aspek teknis dari bahan ajar akuntansi yang dihasilkan meliputi aspek persyaratan sistem, aspek navigasi dan aspek desain. Sedangkan validasi untuk menilai ketepatan aspek edukatif dari bahan ajar akuntansi yang dihasilkan meliputi aspek cakupan materi, tingkat kesulitan, variasi kasus, tingkat kejelasan kasus, dan tingkat kejelasan instruksi kasus. Aspek Teknis

Dari aspek ini diperoleh masukan tentang hal-hal berikut. (1) perlunya disertakan manual penggunaan, semacam HELP, yang berguna untuk membantu user memahami teknis penggunaan masing-masing menu dan dokumen yang ada. Di samping itu, tampilan awal program perlu diperbaiki dengan membuat menu-menu dengan sub menu di dalamnya, sehingga jumlah "tab" pada tampilan awal dapat diminimalisir. (1) Koreksi berikutnya adalah tentang perlunya ditinjau ulang secara 
teknis instruksi pada submenu upload file dalam rangka memfasilitasi ide untuk upgrading kasus karena pada saat divalidasi, sub menu upload file tersebut tidak bisa berjalan sebagaimana mestinya. Masukan-masukan ini telah ditindaklanjuti sebagai penyempurnaan prototipe bahan ajar.

Secara keseluruhan diperoleh pendapat bahwa aspek teknis (persyaratan sistem, navigasi dan desain) pada bahan ajar akuntansi berbasis komputer ini telah cukup memadai dan telah dianggap memenuhi unsur kelengkapan sebagai bahan ajar akuntansi berbasis komputer yang valid dan siap diimplementasikan.

\section{Aspek Edukatif}

Validasi untuk menilai ketepatan aspek edukatif dari bahan ajar akuntansi yang dihasilkan meliputi aspek cakupan materi, tingkat kesulitan, variasi kasus, tingkat kejelasan kasus, dan tingkat kejelasan instruksi kasus.

Hasil validasi menunjukkan bahwa pada aspek cakupan materi telah sesuai dengan fokus penelitian yaitu terdiri dari mengelola dokumen transaksi, mengelola entri jurnal, mengelola buku besar dan neraca saldo, serta menyusun laporan keuangan. Pada aspek tingkat kesulitan, karena penelitian ini fokus pada kompetensi mengelola dokumen transaksi sampai menyusun laporan keuangan maka kompetensi ini dirancang untuk siswa kelas X SMK. Pada level ini, siswa baru diperkenalkan dengan akuntansi dan dengan demikian tingkat kesulitan kasus yang disajikan dalam program telah sesuai untuk siswa pada jenjang pendidikan tersebut. Pada aspek variasi kasus, validator memberikan masukan tentang perlu ditambahkannya beberapa kasus. Namun mengingat pertimbangan peneliti dalam merancang program ini adalah agar guru lebih tertantang untuk membuat kasus baru buatan guru sendiri maka atas masukan ini ditindaklanjuti dengan adanya fasilitas upload file atas kasus baru sehingga guru leluasa untuk mengembangkan dan mengupload kasus yang dibuatnya sendiri. Atas tingkat kejelasan kasus, validator menyarankan agar pada kasus lebih dijelaskan detil perusahaan yang dijadikan kasus. Hal ini dimaksudkan agar siswa mendapatkan background yang cukup kuat dalam memahami kasus perusahaan tersebut. Atas masukan ini telah dilakukan penyempurnan pada produk pengembangan. Sementara pada aspek tingkat kejelasan instruksi kasus, instruksi telah jelas dipaparkan di akhir kasus. Dengan membaca instruksi tersebut, siswa dapat memahami langkah berikutnya yang harus mereka lakukan untuk menyelesaikan kasus tersebut. 
Secara umum, atas pengembangan bahan ajar berbasis komputer ini utamanya pada aspek edukatif telah dinilai valid oleh validator. Validator juga menyarankan bahwa program aplikasi akuntansi ini sangat potensial dan perlu untuk dikembangkan pada kompetensi selain yang menjadi fokus penelitian ini.

\section{SIMPULAN}

Bahan ajar yang dihasilkan dalam penelitian tahap pertama ini adalah berupa prototipe bahan ajar akuntansi berbasis komputer yang dikembangkan berdasar kajian kurikulum serta kajian praktek pembelajaran di lapangan. Topik kompetensi yang dijadikan contoh pengembangan bahan adalah topik-topik kompetensi yang dialokasikan untuk siswa kelas X SMK yang terdiri dari mengelola dokumen transaksi, mengelola entri jurnal, memproses buku besar dan neraca saldo, serta menyusun laporan keuangan. Pada tampilan awal program terdapat 6 menu utama yaitu master, bukti transaksi, proses, laporan, help dan exit. Keseluruhan menu diarahkan untuk mencapai kompetensi yang menjadi fokus pengembangan.

Pengembangan bahan ajar akuntansi berbasis komputer ini mengacu pada dua aspek utama yaitu pengintegrasian materi dari beberapa topik kompetensi yang menjadi fokus pengembangan serta mengacu pada pemahaman bahwa penggunaan media digital berbasis komputer akan membantu siswa menjadi pribadi yang adaptif dengan teknologi informasi dan komunikasi sehingga kompeten memadukan teori akuntansi dengan praktik di dunia kerja yang sarat dengan penggunaan teknologi komputer. Kelayakan dari sisi teknis dan materi telah diuji melalui serangkaian proses validasi pakar. Berdasarkan rekomendasi dari pakar telah dilakukan revisi dan penyempurnaan terhadap produk pengembangan sehingga bahan ajar telah valid dan siap diimplementasikan.

Bahan ajar akuntansi berbasis komputer ini dapat digunakan dalam pembelajaran klasikal maupun individual, tergantung pada strategi dan skenario pembelajaran yang dirancang guru. Meski demikian, disarankan agar guru tetap melakukan pendampingan selama proses belajar mengajar dengan menggunakan bahan ajar ini. Bahan ajar ini dikembangkan tidak untuk meniadakan peran guru. Guru tetap berperan sebagai fasilitator dan rujukan mahasiswa jika mengalami kesulitan dalam memahami dan menyelesaikan kasus dalam bahan ajar. 
Dalam penelitian ini, prosedur pengembangan dan interpretasi terhadap produk pengembangan diarahkan pada kelayakan prototipe produk. Penelitian ini belum melakukan eksperimen serta revisi untuk menghasilkan produk pengembangan final. Proses eksperimen dan revisi akhir direncanakan untuk dilaksanakan pada penelitian tahap kedua/tahun kedua.

\section{DAFTAR RUJUKAN}

Andayani, Endang, S., Irafahmi, Diana, T., Sulastri. 2009. Pengembangan Bahan Ajar Mata Kuliah Praktikum Akuntansi 2 Berbasis CD dengan Program Microsoft Visual Basic. Laporan Penelitian Pengembangan. Malang: Lembaga Penelitian UM

Borg, W. L. and Gall, M. D. 1983. Educational Research: An Introduction. London: Longman, Inc.

Ghee, T. T., Heng, L. T. 2008. Efficacy of Multimedia Teaching Instruction in Elementary Mandarin Class. Media in Foreign Language Teaching and Learning. (Online), http://www.fas.nus.edu.sg/cls/clasic2008/Tan_Lim.pdf

Irafahmi, Diana, T. 2008. Undergraduate Students' Internet Use in an Accounting Department in Indonesia. Thesis tidak diterbitkan di Postgraduate Program Monash University Australia.

Liu, M. 2000. A Look at the Research on Computer-Based Technology Use in Second Language Learning: Review of Literature from 1990-2000. Journal of Research on Technology in Education. (Online), http://jabba.edb.utexas.edu/it/seclangtechrev.pdf

Moore, K. D. 2005. Effective Instructional Strategies: From theory to practice. London: Sage

Pusat Kurikulum. 2007. Naskah Akademik Kajian Kebijakan Kurikulum SMK. (Online),http://www.puskur.net/download/prod2007/45_Kajian\%20Kebijaka n\%20Kurikulum\%20SMK.pdf 